\title{
The Great Gathering of Latin-American Theater People: A Report on the 24th Iberian-American Theater Festival in Cadiz
}

\section{Hedda Kage}

A Herculean effort yields only a meager profit for festival organizers. This could be the final assessment of those eleven days at the end of October, including 27 invited productions from Argentina, Bolivia, Brazil, Chile, Costa Rica, Cuba, Mexico, Peru, Spain, and Uruguay. As a constant observer over the years could verify, this is hardly a surprising balance if one knows the requirements and conditions of artistic decisions. With all due respect to the commendable largess of this atmospherically unrivalled festival of meetings, there were quality snags from time to time. Diplomatic obligations, respect, friendships, a limited budget for travel expenses, and the yearly rhythm neutralize artistic rigor.

The festival founded in 1985 in order to connect Latin America's worlds of theater to the linguistic mother countries Spain and Portugal, and soon to celebrate its twenty-five years of existence in 2010, has most of all succeeded in building and stabilizing bridges over which hundreds of Latin American theater artists have made their way to Europe every year. Cadiz not only offers them the time and space in which to present their own productions, but also the chance to see and learn about the productions of others and, in the accompanying forums and workshops, to engage in exchanges focused on aesthetic positions in the theater and cultural realities. Together, these artists enjoy great hospitality in the common festival hotel, make guest appearances in additional cities of the Iberian Peninsula, and travel from here to other European countries. A year after the return of democracy to Argentina, consolidating Latin America's theater worlds was first achieved in 1984 by Carlos Jiménez, who, born in Cordoba, fled to Venezuela to escape the military junta. The ex-Cordoban, who Venezuela thanks for the theater wonder "Rajatabla" and the Caracas Festival, invited theater people from practically 
every Latin American brother nation to Cordoba to the first Latin-American Theater Festival. In 1985 the same idea was to be adopted in Cadiz by Juan Margolla, and, since twenty-four years, continued by Pepe Bablé: Every year in Cadiz, for a period of eleven days, a portion of the dream of a United States of Latin America, over which independence strategists have probably pondered for 200 years already, is expressed theatrically."

Not without reason was Cadiz declared the 2012 Iberian-American Capital of Culture, and so now it prepares in every area - complete with more architectural visibility - for this honorary year. The over 3000-year-old white city is cleaning up its last tumble-down areas to tourist standards. The city's valued and popular mayor, slyly nicknamed 'the secret Queen Teófila I' by her friends, intends to do everything in her power to make the festival the representative showpiece of the upcoming festivities. On this occasion too, she insisted on personally celebrating the award ceremony in the city hall's palatial room. The festival prize for the life's work of an artist was awarded Patricia Ariza Flores, the Columbian writer, director, actress, cofounder of the famous troupe "La Candelaria" (Bogotá), and many times threatened human rights activist. Awarded for the tenth time, this year's "Atahualpa del Cioppo" prize went to the actor and director Mario Ernesto, also the founder and festival director of the International Hispanic Theater Festival in Miami, Florida. The Cuban-born Ernesto was praised for his tireless, twenty-five years of commitment to nurturing a theatrical Hispanic-American presence in the culture of the United States. Thanks to Teófila's sponsorship, the Iberian-American Meeting for Women in Theater - an outstanding forum for reflection, with its symposiums, workshops and publications, organized every year by Margarita Borja and Diana Raznovich — has meanwhile become an indispensable part of the festival.

Among the most convincing productions of this highly multifaceted program (20 productions with 32 performances in three theaters and seven open-air as well as street-theater productions with 12 performances) were two productions from Spain. From Andalusia came the sensational, solo piece "E1 Testigo" (The Witness) by Fernando Quiniones. Narrating and performing alone and without music, Rafael Alvarez, the actor known as El Brujo (The Wizard), before twelve chairs on the vast and empty stage of the Gran Teatro Falla, brings to life the fictional biography of a rundown Flamenco singer. Even without understanding a single word of the Andalusian idiom, one can follow and be astounded by the extent to which this phenomenal performer celebrates, with dance-like precision, his exclusively spoken Flamenco cho- 
reography and moves the audience to standing ovations. Also residents of Andalusia, known for their absurdist mourning ceremonies for thirty years already, are the members of the troupe La Zaranda, which presented its latest artistic version of chaos, "Futuros Difuntos," in co-production with the Théatre Sorano de Toulouse. In spite of the deep admiration for philosophical folly and clown-like verbal acrobatics, even when some of the uniqueness deteriorates due to sheer repetition, perhaps the autumn of the patriarch has arrived.

Peru was one of the festival's two focal-point countries. Of the three invited productions, only the relentless, inexhaustible work of the theater collective Yuyachkani, founded in 1971 under difficult political circumstances, fulfilled the expectations associated with its name.

"Santiago" is the title of Miguel Rubio Zapata's collaborative stage production, in which a theatrically subtle and poetic connecting of different readings and levels of meaning, removed from all sense of folklore, selfcritically confronts the usual postcolonial reductions as well as the painful inner conflicts and social contradictions that exist in present-day Peru.

(For further information: www.yuyachkani.org)

Chile enchanted with "Gulliver," an extraordinary puppet theater production by actor and director Jaime Lorca, who, for the first time since the disbanding of the famous "La Troppa" company, makes known his return to the theater with a staging of Jonathan Swift's material. The delicate figures' level of artistic sophistication and the spoken-word expertise, combined with brilliantly conceived stage construction and lighting, turn the tale of the frightened giant who wonders if he is God into a small masterfully-crafted marvel. (Also see www.viajeinmovil.cl)

The greatest dramatic achievements clearly came from Argentina. The performances by Daniel Veronese and Claudio Tolcachir have long been delicacies on the international festival circuit. Audiences are familiar with Veronese's method from the Chekov Marathon ("Three Sisters" and "Uncle Vanya"). For this production, when his performers and two guests undergo dramaturgical surgery while performing two of Ibsen's plays about women — the early "A Doll's House," the later "Hedda Gabler" — at once, with no change of light on the garishly lit stage, in a literal sense Veronese attains (especially with "A Doll's House") breathtaking results, even when, as he writes in his explanatory notes, the path of his vision was not quite completed. He made the entanglement even tighter, simultaneously forcing the presentation of both stories into a daring parallelism within the action in 
order to part with this attempt out of respect for the time interval between both works, for the linguistic differences of the two stories, and for Ibsen's atmospheric mastery.

With a stringent and reduced sense of perception, two pieces extremely unalike regarding their range and number of characters are created by two excellent ensembles performing in the same theater space. Though, dramatically speaking, both pieces are rich enough to watch separately, viewers come closer to the concept's mark when they follow the performances side by side to grasp the dramaturgical context of this double-play in the borrowed theater backdrop and given titles rich in allusions: "El desarollo de la civilización venidera" (The Development of the Coming Civilization) and "Todos los grandes gobiernos han evitado el teatro íntimo" (All Major Governments Have Avoided Intimate Theater) respectively, as if Nora were, so to speak, an endless coming and going of Hedda. Since the staging is after all about the tension-ridden connecting of these two women, Nora's explosive dynamics and Hedda's implosive energies, one could splendidly argue about the conceptual balance. In my opinion, Nora is the more extensive and successful attempt. Yet in both pieces the performing excellence is indisputable.

A similarly indisputable and astounding quality exists in the other production from Buenos Aires: "Tercer Cuerpo" (The Third Body) by writer and director Claudio Tolcachir, already in the international success lane with his production "La omisión de la familia Koleman" (The Coleman Family's Omission). The production group, which converted a private home into a combination acting school and theater, goes by the name of "Timbre 4" and obviously relies on the stupendous acting skills of its largely young members. The writer/director defines the setting and time period (a liquidated office) entirely with improvised situations and only later with the dialogue-generated relationships of five downtrodden, homeless people whose desperate-yetcomic depressions are watched and listened to like a string quintet.

(www.timbre4.com)

With the third Argentine production as well, "Choque de Craneos," freely adapted from two Roberto Arlt novels from the 1940s, what convinces most is the surprising musicality and finely-tuned rhythms between the constant transformations of the characters that appear. Since 1983, meaning since returning to Cordoba from his Mexican exile and then going directly into the heart of the Argentine interior, actor-director Paco Giménez has initiated a theater movement from which three regularly working groups emerged: "Los Delincuentes Comunes," "Teatro La Cochera," and "Los que 
dijeron OH!" With a repertoire regularly energized by refreshing restagings, they represent a living contradiction to the established preconceptions of the structurally-limited discontinuity of Argentina's theater system. In contrast to the filigree, mime-oriented finishing touches of the actors from Buenos Aires, able to play out their baffling tensions and tremendously delirious states of mind in the smallest of spaces, Paco Giménez's collaborations consciously place his performers in an open and changeable visual arena in which music, lighting and costumes are elevated to evenly-matched game partners for the characters. Since the legendary staging of Ricardo Bartís's "El pecado que no se puede nombra," the international festival scene has come to know what wonderful theater material can be gained from texts by the Argentine writer Roberto Arlt. With "Choque de Craneos," La Cochera reconfirms this in its own uniquely different and grotesquely playful way.

(For further information also see: www.teatrolacochera.blogspot.com) 
